\title{
Effects of opportunistic feeding by the intertidal gastropods Batillaria zonalis and $B$. flectosiphonata on material flux on a tidal flat
}

\author{
Satomi Kamimura ${ }^{1,2, *}$, Makoto Tsuchiya ${ }^{1}$ \\ ${ }^{1}$ Laboratory of Ecology and Systematics, Graduate School of Engineering and Science, University of the Ryukyus, \\ Nishihara, Okinawa 903-0213, Japan \\ ${ }^{2}$ Present address: Fishery Research Agency, Research Institute of Seto Inland Sea Tidal Zone Environment Section, \\ 2-17-5 Maruishi, Hatsukaichi, Hiroshima 739-0452, Japan
}

\begin{abstract}
The role of the opportunistically feeding gastropods Batillaria zonalis and B. flectosiphonata on the material flux within tidal flat ecosystems was studied using a laboratory tide simulated system. Gastropods were cultured in the system for $2 \mathrm{wk}$ using natural seawater; in one treatment the gastropods were restricted to suspension feeding only, while in the other they were free to engage in suspension and deposit feeding (dual feeding or opportunistic feeding). Clearance rates in both species were higher in the suspension feeding treatment than in the dual feeding treatment, and were maintained on a diet of high concentration particulate nitrogen (PN) in the water column. In the suspension feeding treatment, $B$. zonalis and $B$. flectosiphonata exhibited remarkable biodeposition on the surface sediment, as indicated by chlorophyll a (chl a), pheopigments (pheo), sediment PN and total organic carbon. In contrast, deposition was less evident in the dual feeding and control (no gastropods) treatments. 'Freshness', as indicated by the chl a:pheo ratio in the surface sediment, was higher in the control than in the other treatments. The removal rate of suspended PN by B. zonalis and B. flectosiphonata was variable, although uptake from the suspended matter was 0.7 to 2.0 times greater than that of deposited matter. We conclude that these opportunistically feeding gastropods play a significant and unique role in biodeposition by accumulating organic materials on the surface sediment during suspension feeding, and in decreasing the biodeposition by ingesting the biodeposited materials during deposit feeding.
\end{abstract}

KEY WORDS: Opportunistic feeding $\cdot$ Gastropods $\cdot$ Clearance rate $\cdot$ Deposit feeding $\cdot$ Suspension feeding $\cdot$ Biodeposition $\cdot$ Batillaria

\section{INTRODUCTION}

The feeding activities of marine invertebrates play an important role in the transportation and degradation of organic materials in intertidal flats (Knox 1986, Raffaelli \& Hawkins 1996, Lenihan \& Micheli 2001). There is a wealth of literature relating to suspension and deposit feeders, including their role in the transportation and flux of various substances across the sedimentwater interface. Obligate suspension feeders take particles from the water column and eject their feces and/or pseudofeces onto the sediments, e.g. mussels (Björk et al. 2000), clams (Jie et al. 2001) and oysters (Hayakawa et al. 2001). Deposit feeders are reported to influence the ambient environment in a number of ways, e.g. Littoraria irrorata remove significant amounts of microbes and reduce the total organic matter from decaying grass in salt marshes (Newell \& Barlocher 1993), Yoldia limatula reduce chlorophyll a (chl a) levels in sediments (Ingalls et al. 2000), and Nereis virens and Nucula proxima reduce the organic matter in sediments (Kristensen \& Blackburn 1987, Cheng \& Lopez 1991). 
Some species can reversibly switch their feeding mode, e.g. from deposit to suspension feeding and vice versa. Several terms have been used to describe such feeding mechanisms or strategies: 'interface feeder' was proposed by Dauer et al. (1981) for the polychaetes which utilize foods in the sediment surface, water column and resuspended materials, and this term was used to distinguish the switching feeding mode strategy from obligate feeding strategies. The term 'facultative deposit feeding' was described for the predominantly suspension feeding strategy of the bivalves Macoma balthica (e.g. Goeij \& Luttikhuizen 1998) and Semele solida (Stead at al. 2002). In addition, facultative suspension feeding by dominantly deposit feeders was described for the polychaete Spiochaetopterus oculatus (Bock \& Miller 1997). The manner in which these species respond to changes in environmental conditions has attracted the interest of many researchers. The polychaete Boccardia pugettensis was reported to regulate the balance of time spent between deposit and suspension feeding as a response to changes in food condition (Taghon \& Greene 1992). The gastropod Crepidula fecunda showed both suspension feeding and grazing strategies during its incubation periods (Chaparro et al. 2002). The facultative deposit feeder $M$. balthica feeds on deposited materials at low water (Brafield \& Newell 1961), when they occur at high density (Marinelli \& Williams 2003), and also during their juvenile stage (Rossi et al. 2004). These studies focused on the environmental factors affecting the feeding behavior or strategies of the animals.

The effects of dual feeding species on biogeochemical dynamics in ecosystems have been evaluated for certain polychaetes and bivalves. The polychaete Nereis diversicolor, which is known as an 'occasional' filter feeder (Riisgård 1991) or 'facultative' filter feeder (Vedel \& Riisgård 1993), biodeposits chl $a$ in a manner similar to an obligate suspension feeder (Christensen et al. 2000). It is also known that deposit feeding in this species occurs during phytoplankton-poor periods. The bivalve Corbicula fluminea, which inhabits streams and lakes, can switch its feeding mode between consuming suspended and sediment surface particles (Hakenkamp \& Palmer 1999). It has been shown that pedal feeding can decrease the organic matter content of sediments under laboratory conditions; in the field, however, the impact of filter feeding has the opposite effect through the process of biodeposition of feces and/or pseudofeces (Hakenkamp \& Palmer 1999).

This study focuses on the effects of the suspension and deposit feeding gastropods Batillaria zonalis and B. flectosiphonata, on the biogeochemical dynamics of intertidal flat regions. These gastropods are the dominant species in intertidal flats located in the southern part of Okinawa Island, Japan. Both deposit and suspension feeding modes in B. zonalis and B. flectosiphonata have been observed previously (Kamimura \& Tsuchiya 2004, and authors' unpubl. for B. flectosiphonata). Kamimura \& Tsuchiya (2004) reported the combined effects of dual feeding (suspension and deposit feeding) on the surface sediment and suspended materials; they did not assess the antagonistic effects of suspension or deposit feeding. The purpose of this study is to investigate separately, and in detail, suspension and deposit feeding in the gastropods $B$. zonalis and B. flectosiphonata, and to assess the effects of these 2 feeding modes on material fluxes. We also estimate the rate of nitrogen removal from the ambient environment under the 2 feedings strategies.

\section{MATERIALS AND METHODS}

Collection of animals. Batillaria zonalis and B. flectosiphonata were collected from the Tomigusuku intertidal flat in the southern part of Okinawa Island, Japan $\left(26.5^{\circ} \mathrm{N}, 128^{\circ} \mathrm{E}\right.$, Fig. 1). Snails were collected at random and acclimated in filtered seawater for at least $2 \mathrm{~d}$ prior to being subjected to a period of starvation lasting at least $24 \mathrm{~h}$ before experimentation. Individual gastropods were weighed (wet weight with shell, WW) and sorted into groups. The B. zonalis group comprised 17 individuals weighing 1.46 to $2.79 \mathrm{~g} \mathrm{WW}$ ind. $^{-1}$ and the $B$. flectosiphonata group had 20 individuals weighing 1.14 to $2.65 \mathrm{~g} \mathrm{WW}$ ind. $^{-1}$. These WWs were converted to dry weight (DW, g) without shell using:

$$
\begin{gathered}
\mathrm{DW}=0.0223 \mathrm{WW}+0.0157 \\
\left(\text { B. zonalis, } \mathrm{r}^{2}=0.402, \mathrm{n}=50\right) \\
\mathrm{DW}=0.0675 \mathrm{WW}-0.0467 \\
\left(\text { B. flectosiphonata, } \mathrm{r}^{2}=0.6838, \mathrm{n}=50\right)
\end{gathered}
$$

Experimental design. Each species was subjected to two $14 \mathrm{~d}$ treatments (A and B) between late May and early June 2003. In Treatment A, for each species replicate, samples of a group (see above) were placed in 4 hard plastic cages ( $1 \mathrm{~mm}$ mesh) and the snails were kept 1 to $2 \mathrm{~cm}$ from the sediment surface using a mesh bottom (Fig. 2). Snails in Treatment A cages were able to conduct suspension feeding only, and the nitrogen accumulation to the sediment was estimated. In Treatment B, cages did not have mesh bottoms; this allowed the snails to engage in suspension and deposit feeding. Cages for both treatments were placed within 31 plastic chambers containing sandy sediment. Seawater was passed through the cages via a series of small holes in the base of each chamber. Four replicates of Treatments A and B were conducted for each species and placed in a single 


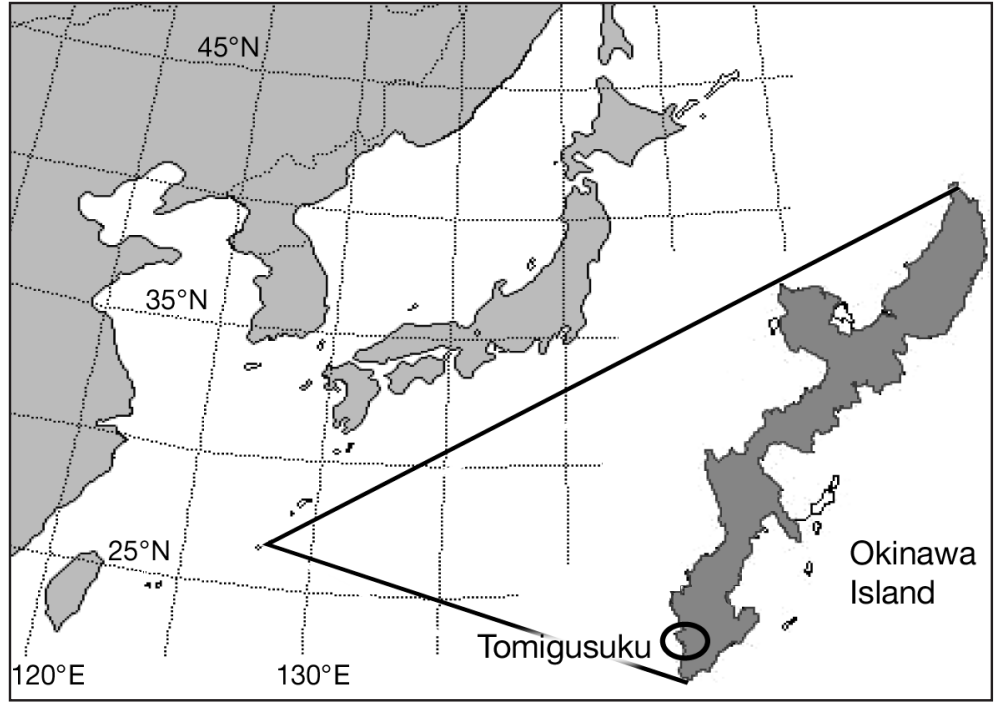

Fig. 1. Location of Okinawa Island and Tomigusuku intertidal flat where Batillaria zonalis and B. flectosiphonata were collected

chambers. Seston was first administered immediately after the chamber had been filled from the bottom. The second and third supplies were performed at 120 min intervals, in order to compensate for the loss of seston due to feeding. A submersible heater was used to maintain the seawater temperature at $25^{\circ} \mathrm{C}$. Four chambers for the control treatment (without snails) were set with 2 replicates for each of the 2 treatments. From each chamber a subsample of the sediment for measuring chl $a$ and pheo was collected in advance of the experiment. In order to avoid excess disturbance, subsamples for sediment particulate nitrogen (PN) and total organic carbon (TOC) analysis were not collected before the experiment, as they required a larger amount of sediment than required for the chl $a$ and pheo measurements.

Estimation of clearance rate (CR) and suspended PN removal rate. Prior to the experiment, we attempted to ascertain a

2001 holding tank, which by automatically filling and draining with natural seawater every $6 \mathrm{~h}$, simulated a flood and ebb flow of a tidal cycle. The simulated tidal cycle took $15 \mathrm{~min}$ to purge and fill. The water levels in each chamber changed from depths of 0 to $14 \mathrm{~cm}$ in the simulated tidal cycle. In order to compensate for the decrease in seston concentration during the simulated high tide, seston in the natural seawater, which is nonfiltered and pumped up from the Tomigusuku intertidal flat, was supplied for $10 \mathrm{~min}$ directly to the top of the

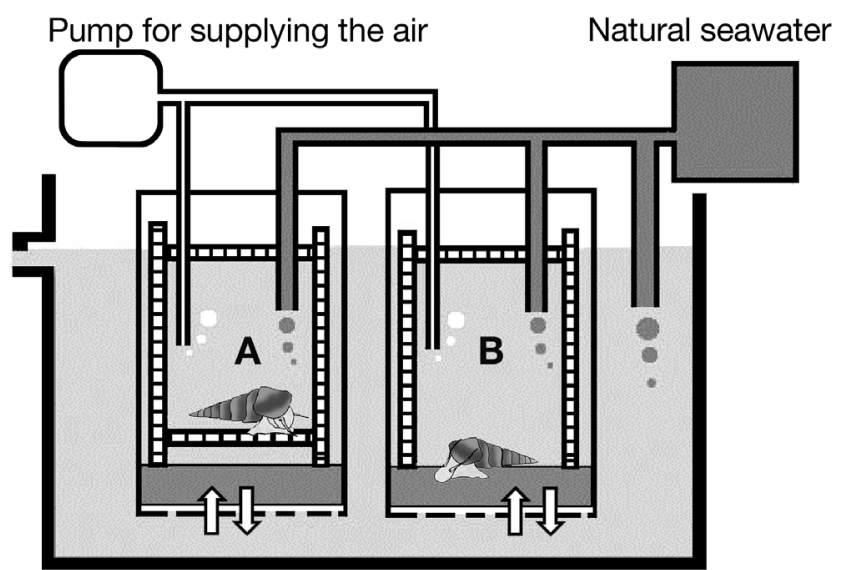

Fig. 2. Laboratory tide simulated experimental design with flood and ebb flow system. Chambers contain Treatment A and B cages. Treatment A cages ( $\mathrm{n}=4$ for each species) are covered with a lid on the top and bottom, and were used for the suspension feeding treatment. Treatment $\mathrm{B}$ cages $(\mathrm{n}=4$ for each species), without bottoms, were used for the dual feeding treatment. Arrows indicate the natural seawater flow in and out through the holes on the bottom of the chamber fast and sensitive method of measuring suspended PN concentration in order to estimate CR. The absorbance of stirred seawater samples can be measured without any pretreatment, but the measuring of suspended PN requires filtration and elaborate processes. Thus, we checked whether measuring the absorbance of natural seawater for our experiment could be an alternative method to measuring suspended PN. Natural seawater was taken from the experimental tank (Fig. 2) and diluted to 7 different concentrations of seston using filtered seawater. Part of the diluted seawater was filtered with preweighed Whatman GF/C filters. Drying $\left(80^{\circ} \mathrm{C}\right)$ and weighing of seston on the filters was repeated until constant weights were obtained. Absorbance of stirred seawater samples at different wavelengths were measured using a spectrophotometer (Shimadzu UV-1650 PC). Suspended PN (on the filters) was measured using a NC analyzer (Sumigraph model NC-80, Sumitomo kagaku kogyo). The most sensitive PN absorbance was found to be at a wavelength of $500 \mathrm{~nm}\left(\mathrm{ABS}_{500}\right)$. The absorbance/suspended $\mathrm{PN}$ relationship is defined as:

$$
\mathrm{PN}\left(\mathrm{mg} \mathrm{l}^{-1}\right)=1.74 \times \mathrm{ABS}_{500}-0.0114
$$

for which $\mathrm{r}^{2}=0.957,0.0177<$ suspended $\mathrm{PN}<0.522$, $0.00833<$ absorbance $<0.307$.

In order to estimate $\mathrm{CR}$, absorbance of seawater was measured in each chamber on the 4th (Day 1) and 7th day (Day 2). After seston was supplied to the chambers (during the simulated high tide, see 'Experimental design' above), seawater in the chamber was aerated for 10 min to uniformly mix the seston. Five ml of seawater was then taken from each chamber and kept in 
test tubes in order to measure the initial concentration. Either 100 or 75 min later, while snails were feeding, $5 \mathrm{ml}$ of seawater was sampled again and automatic supply of natural seawater resumed to all chambers in order to replace the lost seston. This procedure series was repeated 3 times during the simulated high tide, hence the feeding time length of 100 or 75 min was selected. All seawater samples were stored in the refrigerator $\left(4^{\circ} \mathrm{C}\right)$ and absorbance was measured the next day. The absorbance values were converted to suspended PN using Eq. (3).

CR was calculated using a modification of Coughlan's (1969) equation, where CR $\left(\mathrm{l} \mathrm{h}^{-1} \mathrm{~g}^{-1} \mathrm{DW}\right)$ is defined as the volume of water cleared of suspended particles per unit of time (Riisgård \& Ivarsson 1990):

$$
\mathrm{CR}=(V / t \mathrm{DW})\left\{\left[\ln \left(C_{0} / C_{t}\right)\right]-\left[\ln \left(C_{0}{ }^{\prime} / C_{t}{ }^{\prime}\right)\right]_{\text {average }}\right\}
$$

where $V$ is the volume of seawater in the chamber, $t$ is time, $C_{0}$ and $C_{t}$ are the suspended $\mathrm{PN}$ at times 0 and $t$, which define an interval (either 100 or $75 \mathrm{~min}$ ) after seston supply, and $C_{0}{ }^{\prime}$ and $C_{t}^{\prime}$ are the same but for the control culture. $\left[\ln \left(C_{0}{ }^{\prime} / C_{t}^{\prime}\right)\right]_{\text {average }}$ indicates the average value of $\left(C_{0}{ }^{\prime} / C_{t}^{\prime}\right)$ from the control chambers, which is calculated for each interval. The daily suspension feeding time was considered to be $12 \mathrm{~h}$, and CR per day $\left(\mathrm{CR}_{\text {day, }} \mathrm{l} \mathrm{d}^{-1} \mathrm{~g}^{-1} \mathrm{DW}\right)$ was calculated as 12 times the average CR hourly rate as simulated at high tide. This value was calculated in order to compare with other species in the literature.

The amount of suspended PN ( $\left.\mu g \mathrm{~h}^{-1} \mathrm{~g}^{-1} \mathrm{DW}\right)$ removed by Batillaria zonalis and B. flectosiphonata was estimated by:

$$
\text { Suspended } \mathrm{PN} \text { removal }=C_{0} \times \mathrm{CR}
$$

where $C_{0}$ is the suspended PN at time 0. Suspended PN removal per day ( $\mu \mathrm{g} \mathrm{d}^{-1} \mathrm{~g}^{-1} \mathrm{DW}$ ) was calculated as 12 times the hourly suspended PN removal rate. The results were compared with nitrogen removal from the surface sediments.

Estimation of biodeposition and nitrogen removal rate from surface sediment. After $14 \mathrm{~d}$, the Batillaria zonalis and B.flectosiphonata caged groups were transferred to new chambers filled with filtered seawater devoid of food. They were kept for more than $24 \mathrm{~h}$ and the feces they deposited on the plastic bottoms were collected using a pipette. The collected feces were filtered using pre-combusted and pre-weighed Whatman GF/C filters. Total nitrogen (TN) in the feces was measured using the NC analyzer described above.

Surface sediments from the experimental chambers were collected using glass slides, which are effective for sampling the surface layer. Then, using acetone extraction, surface sediment chl a was measured. The concentration of pheo was measured after the addition of 2 or 3 drops $1 \mathrm{~N} \mathrm{HCl}$ to the measured chl a samples
(Tachibana \& Nasu 1994). Chl a indicates living algae, and pheo indicates degradation products of chl $a_{\text {; }}$ therefore, the chl a:pheo ratios can be used to indicate the relative freshness of food (Kamermans 1994).

Aliquots of sediment samples were dried $\left(80^{\circ} \mathrm{C}\right.$ for $48 \mathrm{~h}$ ) and treated with $2 \mathrm{~N} \mathrm{HCl}$ to remove $\mathrm{CaCO}_{3}$ (Yamamuro \& Kayanne 1995), which reduces the accuracy of the organic carbon measurements. After this treatment, the samples were rinsed twice with deionized distilled water and dried again. Sediment PN and TOC in the surface sediment samples were measured using the NC analyzer. The accumulation of nitrogen $\left(\mu \mathrm{g} \mathrm{d}^{-1} \mathrm{~g}^{-1} \mathrm{DW}\right)$ in the surface sediments and sediment PN removal ( $\mu \mathrm{g} \mathrm{d}^{-1} \mathrm{~g}^{-1} \mathrm{DW}$ ) during deposit feeding were calculated as below:

Nitrogen accumulation $=$

$$
\mathrm{DW}_{\mathrm{sf}}\left(\text { sediment } \mathrm{PN}_{\text {sus }}-\text { sediment } \mathrm{PN}_{\text {cont }}\right) /(t \times \mathrm{DW})
$$

Sediment $\mathrm{PN}$ removal $=$

$$
\mathrm{DW}_{\mathrm{sf}}\left(\text { sediment } \mathrm{PN}_{\text {sus }}-\text { sediment } \mathrm{PN}_{\text {dual }}\right) /(t \times \mathrm{DW})
$$

where sediment $\mathrm{PN}_{\text {cont }}$, sediment $\mathrm{PN}_{\text {sus }}$ and sediment $\mathrm{PN}_{\text {dual }}$ are sediment $\mathrm{PN}$ for the control, suspension and dual feeding treatments, respectively, $\mathrm{DW}_{\mathrm{sf}}$ is the dry weight of surface sediment estimated at $37.0 \mathrm{~g}$ (average $\mathrm{SD}=13.1, \mathrm{n}=5$ ), and $t$ is the experimental period (14 d).

Statistical analyses. Data for CR, DW and TN in feces were analyzed by 2 sample $t$-tests for comparison between feeding treatments; a p-value of 0.05 was used to assess significance. Bonferroni/Dunn tests were used to compare the accumulation of chl $a$, pheo, sediment $\mathrm{PN}$ and $\mathrm{TOC}$ in the surface sediments between control and feeding treatments. A familywise $\alpha$-level of 0.05 was used in the Bonferroni/Dunn tests, and p-values of each paired comparison were calculated as 0.05 per number of pairs in a family.

\section{RESULTS}

Clearance rates of Batillaria zonalis and B. flectosiphonata did not differ significantly between the feeding modes (suspension or dual feeding) on Day 1 (Table 1). However, on Day 2, B. zonalis showed higher CRs in the suspension feeding treatments than in the dual feeding treatments ( $t$-test, $\mathrm{p}<0.05)$. On Day 2, B. flectosiphonata also showed significantly higher CRs in the suspension feeding treatments than in dual feeding treatments ( $t$-test, $\mathrm{p}<0.05)$. The seawater measured on Day 2 contained higher concentrations of suspended PN than on Day 1 (Table 1).

There was no significant difference between the DW of feces collected after the suspension and the dual feeding experiments $\left(53.2 \pm 5.8\right.$ and $63.2 \pm 2.5 \mathrm{mg} \mathrm{d}^{-1}$ 
Table 1. Batillaria spp. Clearance rate per day $\left(\mathrm{l} \mathrm{d}^{-1} \mathrm{~g}^{-1} \mathrm{DW}\right)$ and initial concentrations of suspended particulate nitrogen $\left(\mathrm{PN}, \mathrm{mg} \mathrm{l}^{-1}\right)$ in the seawater on measuring Days 1 and 2. Means $\pm \mathrm{SD}$ are shown, and were tested using $t$-test $\left({ }^{*} \mathrm{p}<0.05\right)$

\begin{tabular}{|c|c|c|c|c|c|}
\hline \multirow[t]{2}{*}{ Sampling day } & \multicolumn{2}{|c|}{$\longrightarrow$ B. zonalis } & \multicolumn{2}{|c|}{- B. flectosiphonata -} & \multirow[t]{2}{*}{ Initial conc. } \\
\hline & Suspension feeding & Dual feeding & Suspension feeding & Dual feeding & \\
\hline Day 1 & $11.36 \pm 3.66$ & $8.13 \pm 2.71$ & $7.05 \pm 2.07$ & $6.45 \pm 1.79$ & $0.0710 \pm 0.0202$ \\
\hline Day 2 & $15.18 \pm 4.40^{*}$ & $7.43 \pm 1.55$ & $7.32 \pm 1.52^{*}$ & $5.71 \pm 2.02$ & $0.214 \pm 0.147$ \\
\hline
\end{tabular}

$\mathrm{g}^{-1}$ DW for Batillaria zonalis, and $58.8 \pm 16.4$ and $39.7 \pm$ $5.3 \mathrm{mg} \mathrm{d}^{-1} \mathrm{~g}^{-1} \mathrm{DW}$ for B. flectosiphonata, Fig. 3a, $t$-test, $\mathrm{p}>0.05)$. In addition, $\mathrm{TN}$ in the feces was not significantly different between the feeding modes (Fig. 3b, Table 2, $t$-test, $\mathrm{p}>0.05$ ).

Surface sediment concentrations of $\mathrm{chl}$ a and pheo were lower before the experiments than after (Fig. 4a). Higher concentrations of $\operatorname{chl} a$ were found when Batillaria zonalis and $B$. flectosiphonata were able to feed on suspended materials only $(1.07 \pm 0.28$ and $1.19 \pm 0.21{\mu g ~ g^{-1}}$ sediment WW, respectively, Bonferroni-Dunn test $\mathrm{p}<0.005$, Fig. $4 \mathrm{a}$ ). The control and dual feeding treatments of $B$. zonalis and B. flectosiphonata had similar chl $a$ in the surface sediments $(0.37 \pm 0.09$ for control, $0.33 \pm 0.03$ for $B$. zonalis and $0.28 \pm$ $0.03 \mu \mathrm{g} \mathrm{g}^{-1}$ sediment WW for B. flectosiphonata). The pheo in the surface sediments under suspension feeding treatments was higher $(6.76 \pm 1.89$ for $B$. zonalis and $5.01 \pm 1.01 \mathrm{\mu g} \mathrm{g}^{-1}$ sediment WW for B. flectosiphonata, respectively, Fig. $4 \mathrm{~b}$ ) than in the controls $\left(0.62 \pm 0.07 \mu \mathrm{g} \mathrm{g}^{-1}\right.$ sediment WW), and the dual feeding treatments $(1.36 \pm 0.14$ for $B$. zonalis and $1.02 \pm$ $0.30 \mu \mathrm{g} \mathrm{g}^{-1}$ sediment WW for B. flectosiphonata). The chl a:pheo ratios before the experiment showed no significant difference between the treatments (Fig. 4c). After the experiment, however, the chl a:pheo ratio in the control chamber sediments $(0.608 \pm 0.178$, Fig. $4 \mathrm{c})$ was higher than in the snail treatments $(0.162 \pm 0.014$ and $0.246 \pm 0.0 .039$ for B. zonalis, $0.240 \pm 0.014$ and $0.297 \pm 0.103$ for B. flectosiphonata).

Sediment PN in the suspension feeding treatments was not statistically different between the 2 species $(0.0483 \pm 0.0029$ for Batillaria zonalis and $0.0473 \pm$ $0.0108 \%$ for B. flectosiphonata, Fig. 5a), and these values were higher than in the control treatments $(0.0254 \pm$ $0.0032 \%)$. TOC in the surface sediments was also higher in the suspension feeding treatments $(0.231 \pm 0.013$ for B. zonalis and $0.241 \pm 0.056 \%$ for B. flectosiphonata, respectively, Fig. $5 b)$ than in the controls $(0.129 \pm 0.009 \%)$. However, the dual feeding treatments did not differ significantly from control treatments in sediment $\mathrm{PN}$ $(0.0179 \pm 0.0069 \%$ for B. zonalis and $0.0138 \pm 0.0040 \%$ for B. flectosiphonata), and in TOC $(0.101 \pm 0.017$ and $0.079 \pm 0.018 \%$, respectively).

The amount of accumulated nitrogen on the surface sediment was not remarkably different between Batillaria zonalis and B. flectosiphonata (Table 2). One-fifth of the amount of accumulated nitrogen in the surface sediments was due to the feces produced by $B$. zonalis. For B. flectosiphonata, TN in the feces was measured to be nearly half of the accumulated nitrogen in the surface sediment.
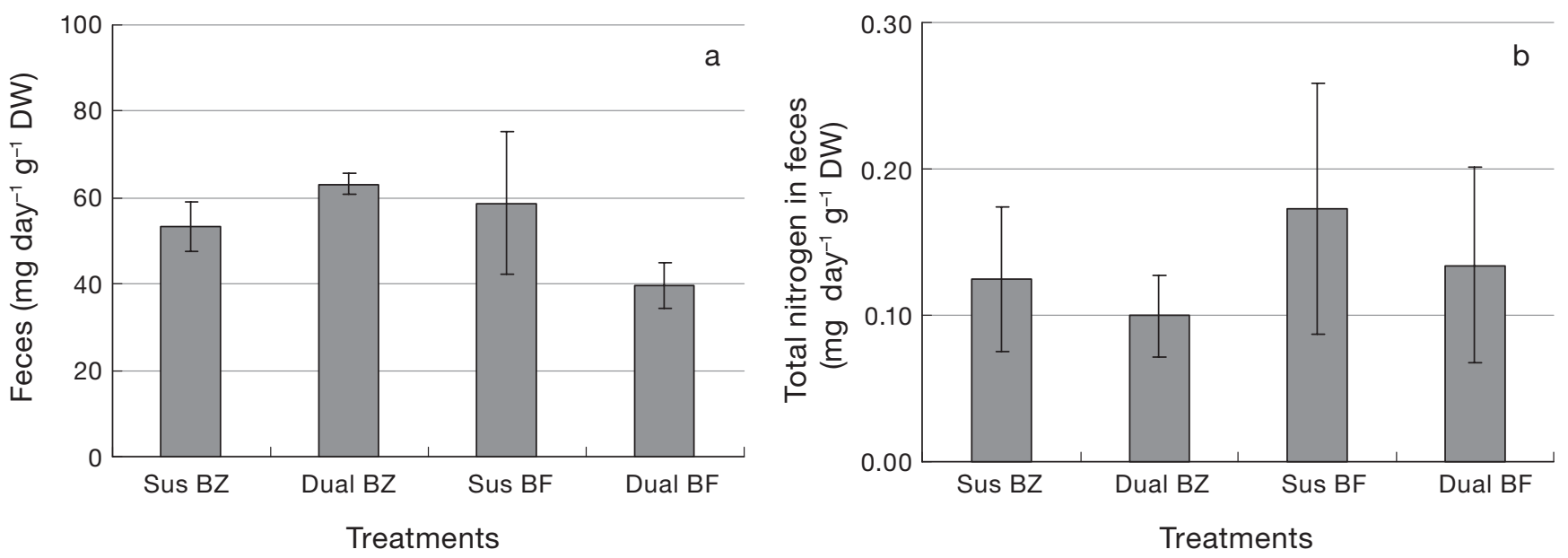

Fig. 3. Batillaria zonalis (BZ) and B. flectosiphonata (BF). (a) Feces dry weight, and (b) total nitrogen contained in feces after experiments. Sus: suspension feeding treatment; Dual: dual feeding treatment. Means \pm SD are shown $(n=4)$ 
Table 2. Batillaria spp. Comparison of total nitrogen (TN) in the feces to the accumulated nitrogen on the sediments

\begin{tabular}{|lccc|}
\hline Species & TN in feces & $\begin{array}{c}\text { Accumulated } \mathrm{N} \\
\text { to the sediments } \\
\left(\mu \mathrm{g} \mathrm{d}^{-1} \mathrm{~g}^{-1} \mathrm{DW}\right)\end{array}$ & $\begin{array}{c}\text { TN in feces: } \\
\text { accumulated } \\
\mathrm{N}(\%)\end{array}$ \\
\hline B. zonalis & $125.1 \pm 49.5$ & $585.9 \pm 77.9$ & $21.8 \pm 10.1$ \\
B. flectosiphonata & $173.4 \pm 85.7$ & $436.9 \pm 215.8$ & $48.6 \pm 31.3$ \\
\hline
\end{tabular}

No significant difference in sediment PN removal was observed between the 2 species (Table 3 ). Removal of suspended PN from the water column by Batillaria zonalis and B. flectosiphonata was higher on Day 2 than on Day 1 (Table 3). On Day 1, the suspended PN removal rate by $B$. zonalis and $B$. flectosiphonata was lower than sediment PN removal. However, on Day 2, when suspended PN concentration was higher than Day 1 (Table 1), the suspended PN removal rate exceeded the sediment $\mathrm{PN}$ removal rate (Table 3 ).

\section{DISCUSSION}

Batillaria zonalis and B. flectosiphonata both show suspension and deposit feeding modes, and play an important role in material fluxes within intertidal ecosystems. When the gastropods were restricted to suspension feeding, both species reduced the concentration of suspended PN in the seawater and the resulting biodeposition on the sediments increased the sediment PN. It is interesting that suspension feeding in these species occurred even when they were free to feed on deposited materials (dual feeding, Table 1). The accumulation of sediment components (sediment $\mathrm{PN}, \mathrm{TOC}, \mathrm{chl} a$ and pheo) during the dual feeding treatments did not differ significantly from the control treatment. These results indicate that the gastropods fed again on the biodeposited materials which were deposited during suspension feeding and explain why the sediment $\mathrm{PN}, \mathrm{TOC}, \mathrm{chl} a$ and pheo were low in the surface sediment. Furthermore, these results support the hypothesis that ' $B$. zonalis need both suspended and deposited materials in the diet' which was previously reported by Kamimura \& Tsuchiya (2004).

On the 7th day (Day 2) of experimentation, suspended PN levels were higher than those observed on the 4th day (Day 1, Table 1). In addition, it can be assumed that nitrogen accumulation in the sediments was also higher on Day 2 as a result of sedimentation and biodeposition. When food conditions were sufficient in both water and sediments, CRs increased in the suspension feeding treatment and actually decreased in the dual feeding treatment, suggesting that Batillaria zonalis and B. flectosiphonata can in- crease CR only when suspension feeding is available; however, both species do not increase CRs during dual feeding, even when they receive adequate amounts of suspended food. In other species, the 'facultative suspension feeder' Nereis diversicolor showed a preference for seston uptake and exhibited remarkable biodeposition but did not feed again on the deposited materials, i.e. deposit feeding (Christensen et al. 2000). Macoma balthica also showed preference for seston when they had enough food on sediments,
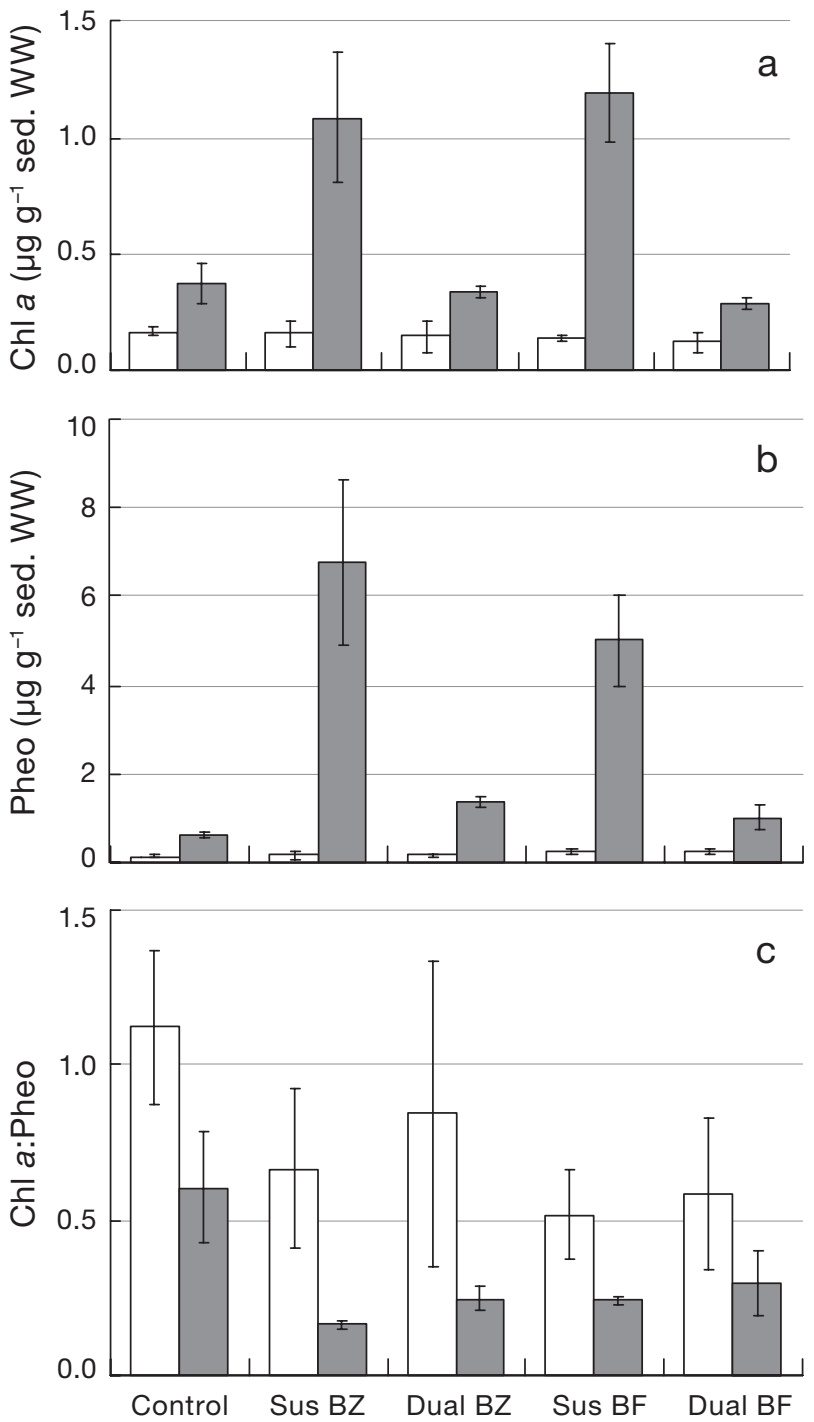

Fig. 4. Batillaria zonalis (BZ) and B. flectosiphonata (BF). (a) Chlorophyll a (chl a), (b) pheopigments (pheo) and (c) the chl a:pheo ratio in the surface sediments (sed.). Sus: suspension feeding treatment; Dual: dual feeding treatment. White bars indicate concentrations before the experiment and gray bars after. Means $\pm \mathrm{SD}$ are shown $(\mathrm{n}=4)$ 

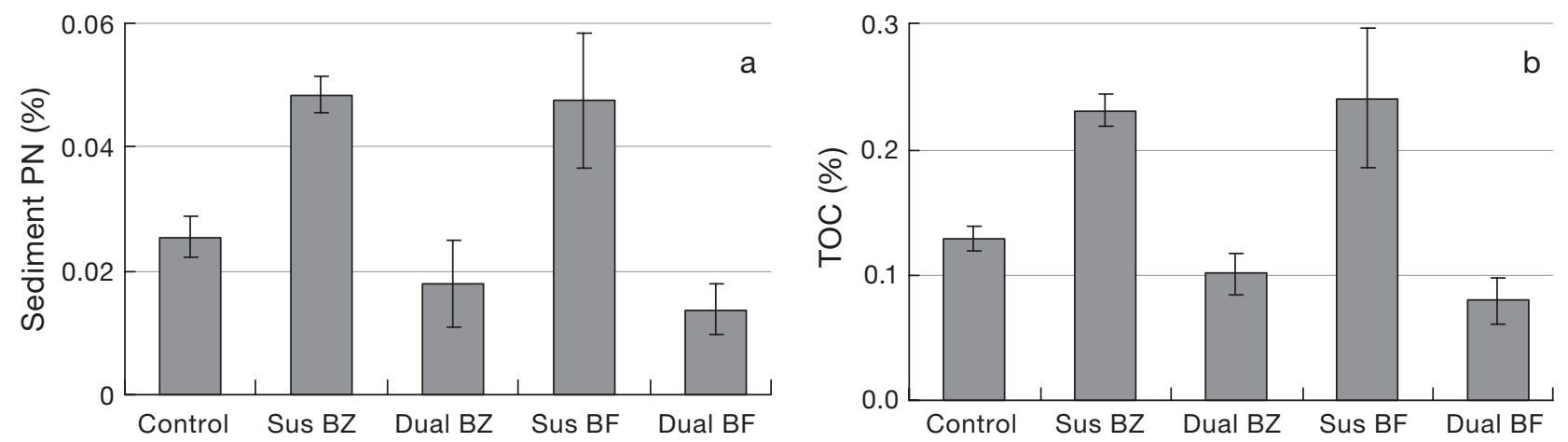

Fig. 5. Batillaria zonalis (BZ) and B. flectosiphonata (BF). (a) Sediment particulate nitrogen (PN) and (b) total organic carbon (TOC) content in the surface sediments. Sus: suspension feeding treatment; Dual: dual feeding treatment. Means $\pm \mathrm{SD}$ are shown $(\mathrm{n}=4)$

but fed on deposited materials only during conditions of high densities (Marinelli \& Williams 2003). The suspension and deposit feeding behavior of B. zonalis and B. flectosiphonata seems to be more flexible and opportunistic with respect to feeding conditions than $N$. diversicolor and M. balthica, and resembles that of Corbicula fluminea (Hakenkamp \& Palmer 1999). Furthermore, fatty acid analysis indicates that B. zonalis consumed the macloalgae Ulva pertusa during the bloom season (Meziane \& Tsuchiya 2000). The flexible nature of the feeding strategies and dietary intake of $B$. zonalis and B.flectosiphonata suggests that both species can be regarded as opportunistic feeders.

Clearance rates for Batillaria zonalis and B. flectosiphonata were estimated to be 0.95 to 1.27 and 0.59 to $0.61 \mathrm{l} \mathrm{h}^{-1} \mathrm{~g}^{-1} \mathrm{DW}$ (Table 1). These results are comparable to the gastropod Crepidula fornicata, which showed the highest $\mathrm{CR}$ at $15^{\circ} \mathrm{C}\left(1.54 \mathrm{l} \mathrm{h}^{-1} \mathrm{~g}^{-1} \mathrm{DW}\right)$; their $\mathrm{CR}$ at $25^{\circ} \mathrm{C}\left(1.03 \mathrm{l} \mathrm{h}^{-1} \mathrm{~g}^{-1} \mathrm{DW}\right.$, data re-calculated from Newell \& Kofoed [1977] as per dry weight), is similar to B. zonalis CR (the same temperature as our study). There are few studies on the CR of gastropods, and it is therefore difficult to compare the CR of opportunistic feeding gastropods with that of obligate suspension feeding gastropods. There are many studies on the filtration activity of suspension feeding bivalves, and the opportunistic feeding bivalve Corbicula fluminea exhibits higher filtration rates than other brackish obligate suspension feeding bivalves at 21 to $24^{\circ} \mathrm{C}$ (Sylvester et al. 2005). In contrast, the pumping rates of the facultative suspension feeders Macoma nasuta and Scrobicularia plana are lower than other obligate suspension feeding bivalves (Hughes 1969, Meyhofer 1985). The CRs of many polychaete species have been reported by Riisgård \& Ivarsson (1990), who observed that the facultative suspension feeder Nereis diversicolor is considered to have an average CR compared to other polychaetes. Bivalves can switch their feeding mode from suspension to deposit feeding far more readily than gastropods and polychaetes. For example, dual feeding bivalves just move their siphons from the sediment surface to the water column and they are able to uptake both suspended and deposited food; in contrast, B. zonalis and Crepidula use the siphon during suspension feeding and the radula in order to uptake deposited materials and/or graze (Newell \& Kofoed 1977, Chaparro et al. 2002, Kamimura \& Tsuchiya 2004). N. diversicolor has organs fixed for carnivorous feeding and they can also form a funnel-shaped net-bag for catching suspended matter (Riisgård 1991). These gastropods and polychaetes have evolved 2 types of morphogenesis and behaviors for 2 kinds of feeding modes, and dual feeding bivalves use 1 organ for 2 types of feeding modes, and have successfully attained the same ability as obligate suspension feeders.

After $14 \mathrm{~d}$ of culturing, the chl a value in surface sediments increased in all chambers, and the values in the suspension feeding treatments were higher than in the dual feeding and control treatments (Fig. 4). The increase in chl $a$ in the control treatment sediments was mostly due to the recruitment of merophyto-

Table 3. Batillaria spp. Comparison of particulate nitrogen (PN) removal from the water column (suspended) and surface sediments

\begin{tabular}{|c|c|c|c|c|c|}
\hline \multirow[t]{3}{*}{ Species } & \multicolumn{3}{|c|}{$\longrightarrow \mathrm{mg} \mathrm{N} \mathrm{d}^{-1} \mathrm{~g}^{-1} \mathrm{DW} \longrightarrow$} & \multicolumn{2}{|c|}{ Suspended PN:Sediment PN removal } \\
\hline & Suspendec & removal & Sediment PN removal & & \\
\hline & Day 1 & Day 2 & & Day 1 & Day 2 \\
\hline B. zonalis & $0.56 \pm 0.11$ & $1.50 \pm 0.15$ & $0.77 \pm 0.17$ & $0.74 \pm 0.15$ & $2.04 \pm 0.56$ \\
\hline B. flectosiphonata & $0.47 \pm 0.13$ & $0.94 \pm 0.14$ & $0.65 \pm 0.10$ & $0.73 \pm 0.20$ & $1.47 \pm 0.29$ \\
\hline
\end{tabular}


plankton and benthic microalgae with non-filtered seawater, which would have occurred in all experimental treatments. Higher chl a contents in the suspension feeding treatments might have originated from the fecal materials ejected by Batillaria zonalis and B. flectosiphonata, since live phytoplankton are included in fecal materials, especially pseudofeces ejected by suspension feeders (e.g. Navarro \& Thompson 1997). Furthermore, suspension feeders can influenced the increase of $\mathrm{chl} a$ in the surface sediment: surviving phytoplankton in the fecal materials can regenerate using nutrients from the fecal materials on the sediment, and suspension feeders can reduce the turbidity and thus increase the intensity of photosynthetically active radiation supporting flourishing microalgae on the surface sediment (Newell et al. 2002, Newell 2004). These suspension feeding effects also influence our experiment and the enriched sediment must be available for deposit feeding $B$. zonalis and B. flectosiphonata.

Measurement of food 'freshness' show that Batillaria zonalis and B. flectosiphonata contribute strongly to maintaining low $\mathrm{chl} a$ :pheo ratios in the sediment. This is evident from the control treatment, which exhibited high chl a:pheo ratios relative to other treatments. Our results are in agreement with previous findings (e.g. Ingalls et al. 2000). Also, Chiantore et al. (1998) demonstrated that feces ejected by suspension feeders showed lower chl a:pheo values than their food.

The feces ejected from Batillaria zonalis and B. flectosiphonata contributed ca. $20 \%$, or less than half, of the nitrogen accumulation in the surface sediments (Table 2). The fecal materials and mucus produced by invertebrates can enhance the growth of microorganisms (Newell 1965, Riemann \& Schrage 1978, Tsuchiya \& Kurihara 1979, Davies \& Beckwith 1999). As such, the feces and mucus produced by B. zonalis and B. flectosiphonata are likely to have supported the growth of microorganisms in this experiment, and could therefore have contributed to nitrogen accumulation in the surface sediments. It appears that the feces gathered after the experiment contained little pseudofeces. Thus, the presence of pseudofeces is likely to underestimate the nitrogen levels in the surface sediments.

Batillaria zonalis and B.flectosiphonata are the dominant species at the collection site, and they coexist with other deposit feeding animals, such as the fiddler crabs Uca perplexa and U. vocans (Okinawa Prefecture Government 2000). B. zonalis and fiddler crabs use the same food sources (microphytobenthic diatoms), as indicated by fatty acid analysis (Meziane $\&$ Tsuchiya 2000). It has been reported for many species - polychaetes (Dauer et al. 1981), bivalves (Stead et al. 2003) and a gastropod (Chaparro et al. 2002) that switching feeding behavior is an efficient strategy under conditions of poor food availability. B. zonalis and B. flectosiphonata may also employ opportunistic feeding strategies to survive when confronted with competition for trophic resources. Whether materials egested by suspension feedings are utilized by coexisting deposit feeders is unclear. Further studies are needed to investigate the important role of $B$. zonalis and B. flectosiphonata in the material flux of organic matter through intertidal ecosystems.

Acknowledgements. We thank the Okinawa Prefectural Land Development Public Corporation and Metocean Environment for their support grant and laboratory systems. We also express our gratitude to Dr. J. Shaw and Dr. K. Okoshi for their helpful suggestions on English terms. Many grateful thanks to the anonymous reviewers for their valuable suggestions and comments.

\section{LITERATURE CITED}

Björk M, Gilek M, Kautsky N, Näf C (2000) In situ determination of PCB biodeposition by Mytilus edulis in a Baltic coastal ecosystem. Mar Ecol Prog Ser 194:193-201

Bock MJ, Miller DC (1997) Particle-bound organic matter as a cue for suspension feeding in tentaculate polychaetes. J Exp Mar Biol Ecol 215:65-80

Brafield AE, Newell GE (1961) The behaviour of Macoma balthica ( L.). J Mar Biol Assoc UK 41:81- 87

Chaparro OR, Thompson JR, Pereda SV (2002) Feeding mechanisms in the gastropod Crepidula fecunda. Mar Ecol Prog Ser 234:171-181

Cheng IJ, Lopez GR (1991) Contribution of bacteria and sedimentary organic matter to the diet of Nucula proxima, a deposit-feeding protobranchiate bivalve. Ophelia 34: $157-170$

Chiantore M, Cattaneo-Vietti R, Albertelli G, Misic C, Fabiano M (1998) Role of filtering and biodeposition by Adamussium colbecki in circulation of organic matter in Terra Nova Bay (Ross Sea, Antarctica). J Mar Syst 17:411-424

Christensen B, Vedel A, Kristensen E (2000) Carbon and nitrogen fluxes in sediment inhabited by suspensionfeeding (Nereis diversicolor) and non-suspension-feeding (N. virens) polychaetes. Mar Ecol Prog Ser 192:203-217

Coughlan J (1969) The estimation of filtering rate from the clearance of suspension. Mar Biol 2:356-358

Dauer DM, Maybury CA, Ewing RM (1981) Feeding behavior and general ecology of several spionid polychaetes from the Chesapeake Bay. J Exp Mar Biol Ecol 54:21-38

Davies MS, Beckwith P (1999) Role of mucus trails and trailfollowing in the behavior and nutrition of the periwinkle Littorina littorea. Mar Ecol Prog Ser 179:247-257

Goeij PD, Luttikhuizen P (1998) Deep-burying reduces growth in intertidal bivalves: field and mesocosm experiments with Macoma balthica. J Exp Mar Biol Ecol 228: 327-337

Hakenkamp CC, Palmer MA (1999) Introduced bivalves in freshwater ecosystems: the impact of Corbicula on organic matter dynamics in a sandy stream. Oecologia 119:445-451

Hayakawa Y, Kobayashi M, Izawa M (2001) Sedimentation flux from mariculture of oyster (Crassostrea gigas) in Ofunato estuary, Japan. J Mar Sci 58:435-444

Hughes RN (1969) A study of feeding in Scrobicularia plana. J Mar Biol Assoc UK 49:805-823 
Ingalls AE, Aller RC, Lee C, Sun MY (2000) The influence of deposit-feeding on chlorophyll-a degradation in coastal marine sediments. J Mar Res 58:631-651

Jie H, Zhinan Z, Zishan Y, Widdows J (2001) Differences in the benthic-pelagic particle flux (biodeposition and sediment erosion) at intertidal sites with and without clam (Ruditapes philippinarum) cultivation in eastern China. J Exp Mar Biol Ecol 261:245-261

Kamermans P (1994) Similarity in food source and timing of feeding in deposit- and suspension-feeding bivalves. Mar Ecol Prog Ser 104:63-75

Kamimura S, Tsuchiya M (2004) The effect of feeding behavior of the gastropods Batillaria zonalis and Cerithideopsilla cingulata on their ambient environment. Mar Biol 144:705-712

Knox GA (1986) Estuarine ecosystems: a systems approach. CRC Press, Boca Raton, FL

Kristensen E, Blackburn TH (1987) The fate of organic carbon and nitrogen in experimental marine sediment systems: influence of bioturbation and anoxia. J Mar Res 45:231-257

Lenihan HS, Micheli F (2001) Soft-sediment communities. In: Bertness MD, Gaines SD, Hay M (eds) Marine community ecology. Sinauer Associates, Sunderland, MA, p 253-287

Marinelli RL, Williams TJ (2003) Evidence for density-dependent effects of infauna on sediment biogeochemistry and benthic-pelagic coupling in nearshore systems. Estuar Coast Shelf Sci 57:179-192

Meyhofer E (1985) Comparative pumping rate in suspensionfeeding bivalves. Mar Biol 85:137-142

Meziane T, Tsuchiya M (2000) Fatty acid as tracers of organic matter in the sediments and food web of a mangrove/ intertidal flat ecosystem, Okinawa, Japan. Mar Ecol Prog Ser 200:49-57

Navarro JM, Thompson RJ (1997) Biodeposition by the horse mussel Modiolus modiolus (Dillwyn) during the spring diatom bloom. J Exp Mar Biol Ecol 209:1-13

Newell RC (1965) The role of detritus in the nutrition of two marine deposit-feeders, the prosobranch Hydrobia ulvae and the bivalve Macoma balthica. Proc Zool Soc Lond 144: $25-45$

Newell RC, Kofoed LH (1977) The energetics of suspensionfeeding in the gastropod Crepidula fornicata L. J Mar Biol Assoc UK 57:161-180

Newell RIE (2004) Ecosystem influence of natural and cultivated populations of suspension-feeding bivalve molluscs: a review. J Shellfish Res 23:51-61

Newell RIE, Cornwell JC, Owens MS (2002) Influence of simulated bivalve biodeposition and microphytobenthos on sediment nitrogen dynamics: a laboratory study. Limnol Oceanogr 47:1367-1379

Newell SY, Barlocher F (1993) Removal of fungal and total organic matter from decaying cordgrass leaves by shredder snails. J Exp Mar Biol Ecol 171:39-49

Okinawa Prefecture Government (2002) Metocean Environment, Environmental report in Tomigusuku intertidal flat for development project (4). Okinawa Prefectural Land Development Public Corporation, Naha (in Japanese)

Raffaelli D, Hawkins S (1996) Intertidal ecology. Kluwer Academic Publishers, Dordrecht

Riemann F, Schrage M (1978) The mucus-trap hypothesis on feeding of aquatic nematodes and implications for biodegradation and sediment texture. Oecologia 34:75-88

Riisgård HU (1991) Suspension feeding in the polychaete Nereis diversicolor. Mar Ecol Prog Ser 70:29-37

Riisgård HU, Ivarsson NM (1990) The crown-filament pump of the suspension-feeding polychaete Sabella penicillus: filtration, effect of temperature, and energy cost. Mar Ecol Prog Ser 62:249-257

Rossi F, Herman PMJ, Middelburg JJ (2004) Interspecific and intraspecific variation of delta C-13 and N-15 in deposit- and suspension-feeding bivalves (Macoma balthica and Cerastoderma edule): evidence of ontogenetic changes in feeding mode of Macoma balthica. Limnol Oceanogr 49:408-414

Stead RA, Clasing E, Lardies MA, Arratia LP, Urrutia G, Garrido O (2002) The significant of contrasting feeding strategies on the reproductive cycle in two coexisting tellinacean bivalves. J Mar Biol Assoc UK 82:443-453

Stead RA, Thompson RJ, Jaramillo JR (2003) Absorption efficiency, ingestion rate, gut passage time and scope for growth in suspension- and deposit-feeding Yoldia hyperborea. Mar Ecol Prog Ser 252:159-172

Sylvester F, Dorado J, Boltovskoy D, Juarez A, Cataldo D (2005) Filtration rates of the invasive pest bivalve Limnoperna fortunei as a function of size and temperature. Hydrobiologia 534:71-80

Tachibana M, Nasu Y (1994) Chlorophyll. In: Nasu Y, Tachibana H, Kawamura S, Tsuzuki T, Tanaka S (eds) Water analysis. Kagaku-Dojin Publishing, Kyoto, p 273-277

Taghon GL, Greene RR (1992) Utilization of deposited and suspended particulate matter by benthic 'interface' feeders. Limnol Oceanogr 37:1370-1391

Tsuchiya M, Kurihara Y (1979) The feeding habits and food source of the deposit-feeding polychaete Neanthes japonica (Izuka). J Exp Mar Biol Ecol 36:79-89

Vedel A, Riisgård HU (1993) Filter-feeding in the polychaete Nereis diversicolor: growth and bioenergetics. Mar Ecol Prog Ser 100:145-152

Yamamuro M, Kayanne H (1995) Rapid direct determination of organic carbon and nitrogen in carbonate-bearing sediments with a Yanaco MT-5 CHN analyzer. Limnol Oceanogr 40:1001-1005

Submitted: July 8, 2004; Accepted: January 9, 2006

Proofs received from author(s): July 7, 2006
Editorial responsibility: Otto Kinne (Editor-in-Chief), Oldendorf/Luhe, Germany 